微小部 X 線による高周波焼入鋼の硬化層深さの非破壊評価 ${ }^{\dagger}$

$$
\begin{aligned}
& \text { 坂井田 喜 久* 柏木章 吾** 沢 木 洋 三* } \\
& \text { 吉田始***片 桐嘉 門**** }
\end{aligned}
$$

\title{
Nondestructive Prediction of Induction-Hardened Zone Depth in Carbon Steel by Micro X-Ray Beam
}

\author{
by \\ Yoshihisa Sakaida ${ }^{*}$, Shogo Kashiwagi ${ }^{* *}$, Yozo SawaKI ${ }^{*}$, \\ Hajime Yoshida $^{* * *}$ and Kamon KatagIRI ${ }^{* * * *}$
}

\begin{abstract}
In order to develop the nondestructive outgoing inspection method that determines the surface conditions in the induction-hardened carbon steel, X-ray diffraction method was applied both to estimate the surface hardness and to predict the hardened zone depth using micro X-ray beam adjusted by the pinhole collimator. In this study, S48C hardened specimen cut from the root circle of drive gear was used. The Vickers hardness distribution and 2/5-value breadth of X-ray diffraction patterns of 100, 200 and 211 planes for ferrite and martensite phases were measured from the hardened zone, and then a correlation between hardness and $2 / 5$-vale breadth was examined. As a result, the hardness of the induction-hardened zone was proportional to the $2 / 5$-value breadth. From the obtained relationship, the surface hardness could be nondestructively estimated by measuring the $2 / 5$-value breadth from the induction hardened carbon steel. Furthermore, by making a master curve for the subsurface hardness distribution of the mass produced parts in the optimum condition, the residual hardened zone depth could be also predicted from the measured 2/5-value breadth. The predicted hardened zone depths in the induction hardened drive gear agreed very well with the results measured by removing the surface layer.
\end{abstract}

Key words : Micro X-ray beam, Nondestructive inspection, Hardness, Hardened zone depth, Carbon steel, Induction hardening

\section{1 緒—言}

バイクや自動車のドライブギアなどの柬車部品は過酷 な環境下で使用されるため, 㐘部表面を高周波焼入して 硬化層を形成し，柬車の硬さだけでなく，耐摩耗性や疲 労寿命などを向上させている.1) 3) しかし, 焼入状態を部 品の外観のみから判断することは困難で，焼入後の部品 を切出して断面硬さを測定し，硬化層深さを把握する抜 取り破壊検査を行わなければならない。抜取り破壊検査 は，一旦生産ラインを中断しなければならないことや全 数保証できないことから, 硬化層深さの非破壊評価が切 望されている.

本研究では, X 線法に注目し, 高周波焼入鋼の硬化層 の硬さと組織や X 線的性質との関係 ${ }^{4)}$ を明らかにするこ とにより，微小部 X 線により高周波焼入した歯部表面の 硬さと硬化層深さを非破壊評価する手法を検討した。

\section{$2 \cdot 1$ 供試材および試験片}

\section{2 実 験 方 法}

供試材は， S48C 炭素鋼のドライブギアである。実験 には, Fig. 1 (a)に示すドライブギアの菊底近傍から切出 した直方体試験片を用いた，試験片寸法は，幅 $5.6 \mathrm{~mm} \times$
蒾幅 $15.8 \mathrm{~mm} \times$ 高さ $10.8 \mathrm{~mm}$ である. ドライブギア㐘部 は，ガス軟窒化後， $900^{\circ} \mathrm{C}$ 高周波焼入， $300^{\circ} \mathrm{C}$ 焼戻しを 行った. Table 1 は，供試材の高周波焼入前の組成成分 を示す。なお，試験片上面に Fig. 1 (b)に示す直交座標 系 $x y z$ を定義した.

Table 1 Chemical composition of virgin S48C.

\begin{tabular}{c|c|c|c|c|c|c|c|c}
\hline $\mathrm{C}$ & $\mathrm{Si}$ & $\mathrm{Mn}$ & $\mathrm{P}$ & $\mathrm{S}$ & $\mathrm{Cu}$ & $\mathrm{Ni}$ & $\mathrm{Cr}$ & $\mathrm{Pb}$ \\
\hline 0.47 & 0.29 & 1.02 & 0.025 & 0.058 & 0.01 & 0.02 & 0.09 & 0.13 \\
\hline \multicolumn{6}{c}{ unit: mass\% }
\end{tabular}

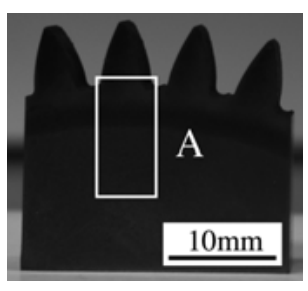

(a) Induction hardened gear

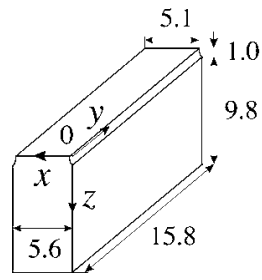

(b) Detail of A
Fig. 1 Cut specimen of S48C carbon steel gear.

$\dagger$ 原稿受理 平成 17 年 10 月 11 日 Received Oct. 11, 2005

* 正 会員 静岡大学工学部機械工学科 †432-8561 浜松市城北, Dept. of Mech. Eng., Shizuoka Univ., Johoku, Hamamatsu, 432-8561

** 学生会員 静岡大学大学院 †432-8561 浜松市城北, Graduate Student, Shizuoka Univ., Johoku, Hamamatsu, 432-8561

$* * *$ 静岡大学工学部機械工学科 ₹432-8561 浜松市城北, Dept. of Mech. Eng., Shizuoka Univ., Johoku, Hamamatsu, 432-8561

****スズキ(株)干432-8611＼cjkstart浜松市高塚町, Suzuki Motor Co., Takatsuka-cho, Hamamatsu, 432-8611 


\section{$2 \cdot 2$ 硬度測定}

$\mathrm{X}$ 線的性質を測定する前に，切出し試験片の側面 $(x z$ 平面）と歯底面（ $x y$ 平面）に対して硬度測定を行い，歯 車側面と歯底面の半径方向（歯底からクランクシャフト 軸方向）の硬度分布を測定した。硬度測定は，微小硬度 計（HM-122，アカシ製）により行った。実験は，まず， 一定の硬さに熱処理した供試材と同じ組成成分の S48C 試 験片を用いて硬度測定条件を決定した後，高周波焼入し た直方体試験片のビッカース硬度を $0.5 \mathrm{~mm}$ 間隔でマッピ ング測定した。次に，直方体試験片側面の $z$ 方向の硬度 分布から，歯底面を逐次研磨する材料除去量 $\Delta z$ を決定し， 研磨面の X 線的性質を測定後, 硬度分布を測定した。

なお，試験荷重の保持時間は 15 秒とし，材料除去は エメリー紙による機械研磨後, 約 $20 \mu \mathrm{m}$ 電解研磨して仕 上げ面とした。な打，機械研磨には，\#80，\#180，\#320， \#600，\#1500，\#8000の6 種類のエメリ一紙を用いた。ま た，電解研磨は，過塩素酸とエタノールを混合した電解 液 ${ }^{5)} よ よ り$ 行った。

\section{$2 \cdot 3 \mathrm{X}$ 線による回折線幅の測定}

$\mathrm{X}$ 線的性質として回折線幅 ${ }^{4}$ に注目し, 研磨面のフェ ライト相またはマルテンサイト相の回折線強度分布を測 定して回折線幅を求めた。 回折線強度分布は, 微小部 X 線回折装置（RINT2100，理学電機製）により測定した。

実験は $\mathrm{Cr}-\mathrm{K} \alpha$ 線を用いて， $\phi 1.0 \mathrm{~mm} ， ま た は ， \phi 0.1 \mathrm{~mm}$ のピンホールコリメータで X 線をマイクロビーム化し， 照射位置の回折線強度分布を湾曲型 PSPC (Position sensitive proportional counter) により測定した. Table 2 に主な X 線回折条件を示す。なお，コリメータ径 $\phi 1.0 \mathrm{~mm}$

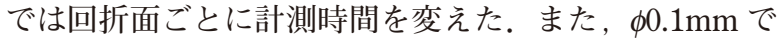
は $\phi$ 軸摇動を行い， 110 面と 211 面のみ測定した.

\section{3 実験結果および考察}

\section{$3 \cdot 1$ 歯車試験片側面と歯底面の硬度分布}

㐘車試験片の硬度分布を測定する前に，硬度 HV325に 熱処理した S48C を用いて試験荷重 $P=9.8 \times 10^{-2} \sim 9.8 \mathrm{~N}$ の荷重条件でビッカース硬度を測定し，測定条件を検討 した。その結果, 硬度測定值が安定する荷重条件は $P \geqq$ $4.9 \mathrm{~N}$ であった. 本研究では, 切出し試験片の柬底面を逐 次研磨し, 研磨面の硬度分布を測定するため, 圧痕深さ はできるだけ浅い方が良い。よって，以下の硬度測定は すべて $P=4.9 \mathrm{~N}$ で行った。

Fig. 2 は，ドライブギア側面 $(x z$ 平面）の硬度分布を 示す. また, Fig. 3 は焼入れ後の代表的な組織写真を示

Table 2 X-ray conditions.

\begin{tabular}{l|c|c}
\hline Characteristic X-ray & \multicolumn{2}{|c}{$\mathrm{Cr}-\mathrm{K} \alpha$} \\
\hline Irradiated area $\left(\mathrm{mm}^{2}\right)$ & $\phi 1.0$ & $\phi 0.1$ \\
\hline Tube voltage $(\mathrm{kV})$ & 35 & 40 \\
\hline Tube current $(\mathrm{mA})$ & 10 & 25 \\
\hline Diffraction & $110, \quad 200$, & 211 \\
\hline Diffraction angle (deg) & $68.79, \quad 105.93$, & 156.87 \\
\hline Fixed time (sec.) & $100,360, \quad 150$ & 840,1200 \\
\hline Oscillation angle (deg) & 0 & $\phi= \pm 180$ \\
\hline
\end{tabular}

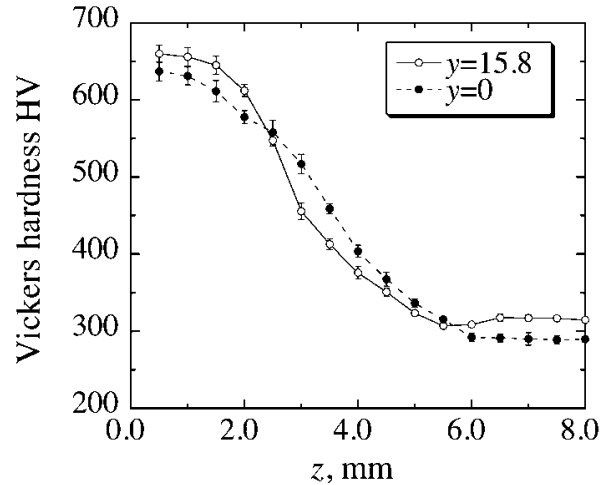

Fig. 2 Vickers hardness distribution near the dedendum circle in the side-face of drive gear wheel.

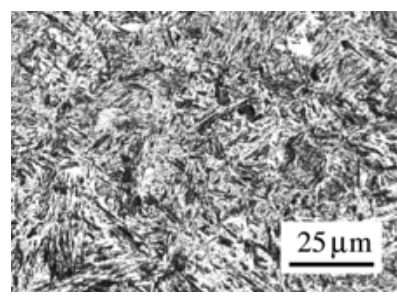

(a) Martensite microstructure at $z=0$

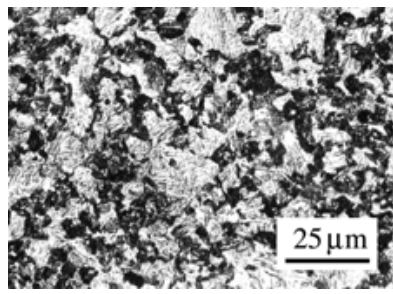

(c) Transitional microstructure at about $z=3.0 \mathrm{~mm}$

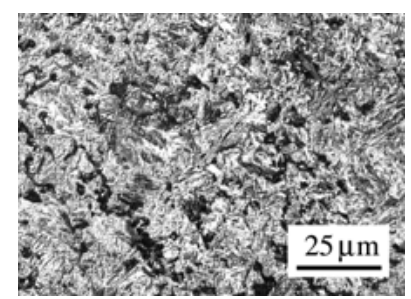

(b) Transitional microstructure at about $z=2.5 \mathrm{~mm}$

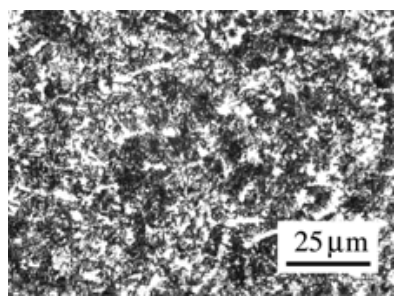

(d) Hypoeutectoid microstructure at $z \geqq 6.0 \mathrm{~mm}$
Fig. 3 Microstructures near induction-hardened zone.

す. $0 \leqq z \leqq 1.5 \mathrm{~mm}$ では，Fig. 3 (a)に示すように高周 波焼入による焼入組織（マルテンサイト組織）が観察さ れ，その領域での硬度の平均值は HV640 20 であった。 一方， $z \geqq 6.0 \mathrm{~mm}$ では，Fig. 3 (d)に示すように焼入前 組織（フェライト十パーライト組織）が観察され，硬度 はほぼ一定值 $(H V 303 \pm 13)$ を示し，その值は焼入前の柬 車の硬度と一致した。また， $1.5 \leqq z \leqq 6.0 \mathrm{~mm}$ では， Fig. 3 (b) や Fig. 3 (c)に示すように焼入組織と焼入前組 織が混在した中間組織が観察され， $z$ の増加とともに硬 度は減少した。 そこで， $0 \leqq z \leqq 1.5 \mathrm{~mm}$ では，材料除去 量を $\Delta z=0.5 \mathrm{~mm}$ に設定した。また， $1.5 \leqq z \leqq 5.0 \mathrm{~mm}$ では， $\Delta z=0.3 \mathrm{~mm}$ に設定し，歯底面から逐次研磨除去 したときの回折線幅と硬度分布を測定した。

Fig. 4 は， $z=1.5 \mathrm{~mm}$ に打ける菊底面（ $x y$ 平面）と平 行な面での硬度分布を示す. $z=0 \mathrm{~mm}$ では測定面内の組 織はすべて焼入組織を示し，ほぼ一定の硬度を示したの に対して, $z=1.5 \mathrm{~mm}$ では歯幅中央付近で焼入組織と焼 入前組織が混在した中間組織が現れ，硬度低下が生じて いる，柬車の高周波焼入では，側面や㐘先表面に焼きが 入りやすいが，歯の内部や歯幅中央部では焼きが入り難 


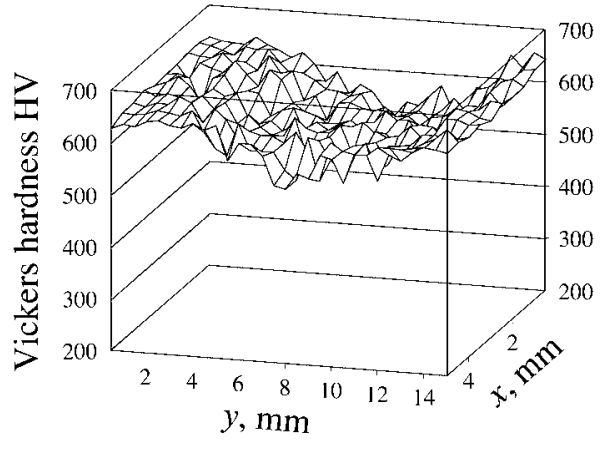

Fig. 4 Vickers hardness distribution at $z=1.5 \mathrm{~mm}$ on the tangent surface to the root circle of drive gear wheel.

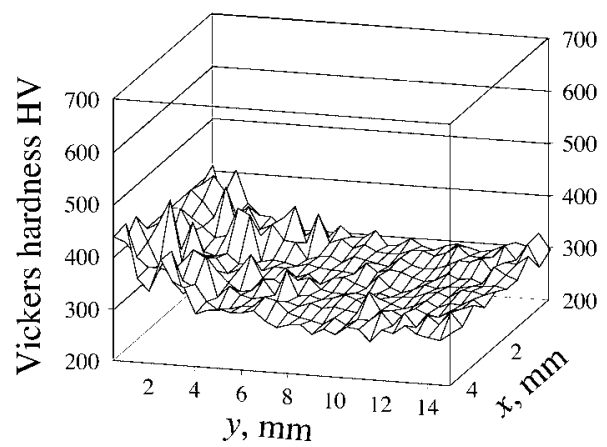

Fig. 5 Vickers hardness distribution at $z=3.3 \mathrm{~mm}$ on the tangent surface to the root circle of drive gear wheel.

いため, 中央付近の硬度が低下した。一方，Fig. 5 は， $z=3.3 \mathrm{~mm}$ に打ける㐘底面（ $x y$ 平面）と平行な面での硬 度分布を示す. Fig. 2 からわかるように柬車側面の硬度 はまだ $400 〜 450$ と高く, 側面近傍に硬化層が一部残留 しているが，歯幅中央部では硬化層はほとんど除去され ていることがわかる.

\section{$3 \cdot 2$ 高周波焼入前後の $\mathbf{X}$ 線的性質の変化}

Fig. 6 は, 焼入前後の㐘底表面から測定した X 線回折 パターンを示す。焼入前の回折パターンは, 焼入前組織 のフェライト相からの 110 面と 200 面, 211 面の 3 つの 回折線が現れているのに対して, 焼入後の回折パターン は，焼入組織のマルテンサイト相からの回折線が現れ， 回折線幅が広がっていることがわかる。同様の傾向は，

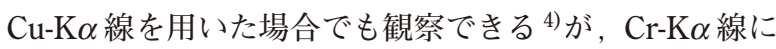
よる回折線は，バックグラウンドが低く, S/N 比も高い

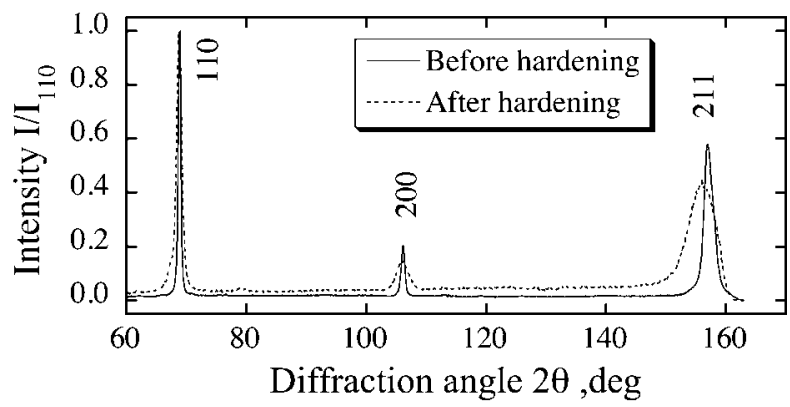

Fig. 6 X-ray diffraction patterns before and after hardening from S48C of drive gear wheel.
ことから，回折線幅変化の測定精度が高い。

なお，回折線幅としては一般に半值幅を採用すること が多いが，焼入前組織のフェライト相からの回折強度分 布が $\mathrm{K} \alpha_{1}$ 線と $\mathrm{K} \alpha_{2}$ 線の重畳によりスプリットし，半值幅 を測定できない場合があることを考慮して，本研究では， 回折強度分布から $\mathrm{K} \alpha_{2}$ 線を分離しない状態で回折線幅が 測定できる $2 / 5$ 值幅 ${ }^{4), 6)}$ を採用した。以下，各回折線の $2 / 5$ 值幅を $W$ と定義した。

\section{$3 \cdot 3$ コリメータ径 $\phi 1.0 \mathrm{~mm}$ による回折線幅の測定 結果}

前節の結果から，歯底面を逐次除去した研磨面にマイ クロビーム化したX 線を照射し，照射位置の回折線幅を 測定するとともにビッカース硬度を測定して，回折線幅 と硬度の関係を実験的に求めた。なお， $\phi 1.0 \mathrm{~mm}$ 扎よび $\phi 0.1 \mathrm{~mm}$ の $\mathrm{X}$ 線照射領域とビッカース圧痕は，Fig. 7 に 示すような位置関係にある。そこで，コリメータ径 $\phi 1.0 \mathrm{~mm}$ で測定した照射位置の硬度は，次式のように， Fig. 7 (a)に示す照射中心と周囲 4 点の平均值とした.

$$
\mathrm{HV}=\frac{1}{5}\left(\sum_{i=0}^{4} \mathrm{HV}_{i}\right)
$$

Fig. 8 は，コリメータ径 $\phi 1.0 \mathrm{~mm}$ による $2 / 5$ 值幅 $W$ とビッカース硬度 HVの関係を示す。困より，2/5 值幅 $W$ と硬度 HV の関係は，ほぼ比例関係を示すことがわか る.そこで, Table 3 に示す焼入組織のマルテンサイト 相の最大回折線幅 $W_{\text {max }}$ と最大硬度 $\mathrm{HV}_{\text {max }}$ を 1 , 焼入前 組織のフェライト相の最小回折線幅 $W_{\text {min }}$ と最小硬度 $\mathrm{HV}_{\text {min }}$ を 0 として縦軸と横軸をそれぞれ次式のように規

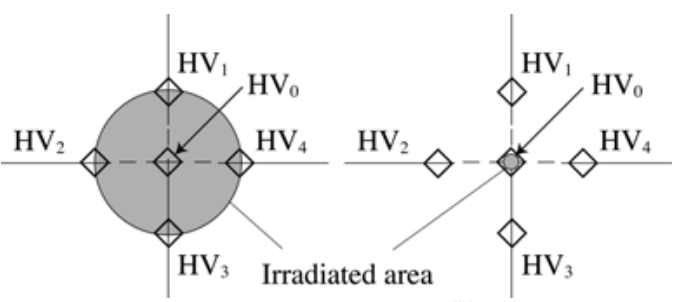

(a) $\phi 1.0 \mathrm{~mm}$

(b) $\phi 0.1 \mathrm{~mm}$

Fig. 7 Measurement of X-ray diffraction pattern and Vickers hardness for lapped surface of drive gear wheel.

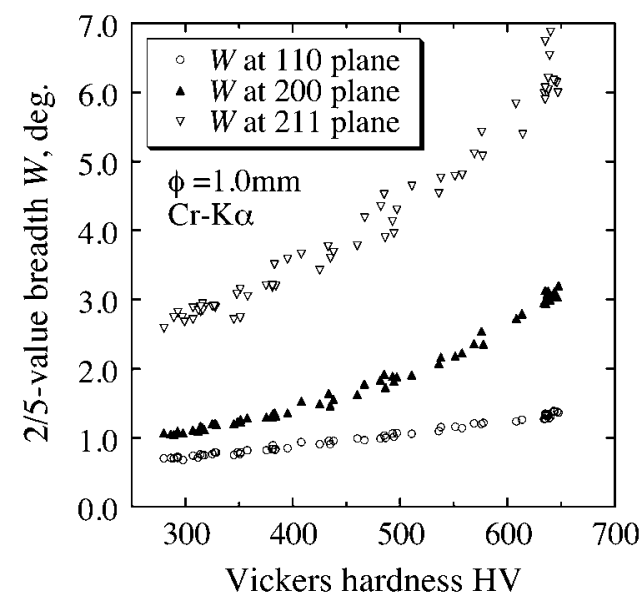

Fig. 8 Relationship between $\mathrm{HV}$ and $W$ measured by micro X-ray beam using $\phi 1.0 \mathrm{~mm}$ collimator. 
Table 3 The Maximum and minimum values of $\mathrm{HV}$ and $\mathrm{W}$ for induction hardened drive gear wheel.

\begin{tabular}{|c|c|c|c|c|c|c|c|c|}
\hline & \multicolumn{4}{|c|}{ Martensite layer } & \multicolumn{4}{|c|}{ Base layer } \\
\hline & \multirow[t]{2}{*}{$\mathrm{HV}_{m a}$} & \multicolumn{3}{|c|}{$W_{\max }$ (deg.) } & \multirow[t]{2}{*}{$\mathrm{HV}_{\min }$} & \multicolumn{3}{|c|}{$W_{m i n}($ deg. $)$} \\
\hline & & 110 & 200 & 211 & & 110 & 200 & 211 \\
\hline$\phi 1.0$ & 646 & 1.38 & 3.13 & 6.51 & 284 & 0.70 & 1.06 & 2.74 \\
\hline$\phi 0.1$ & 652 & 1.28 & - & 6.52 & 289 & 0.55 & - & 2.77 \\
\hline
\end{tabular}

格化し，硬度と回折線幅の関係を再整理した。

$$
\begin{aligned}
& W^{\prime}=\frac{W-W_{\text {min }}}{W_{\text {max }}-W_{\text {min }}} \\
& \mathrm{HV}^{\prime}=\frac{\mathrm{HV}-\mathrm{HV}_{\text {min }}}{\mathrm{HV}_{\text {max }}-\mathrm{HV}_{\text {min }}}
\end{aligned}
$$

その結果を Fig. 9 に示す. また, Fig. 10 は，3つの回折 面に対し， $W^{\prime}$ と $\mathrm{HV}^{\prime}$ の関係をそれぞれプロットした結果 を示す。なお，各点の硬度 $\mathrm{HV}^{\prime}$ は，式 (1)で求めた $\mathrm{HV}$ を 規格化した值でプロットし，その点での硬度誤差をエラー バーで示した。エラーバーが大きいほど X 線照射内の硬 度変化が大きいことを示している。ここで，各回折面の 回折線幅 $W^{\prime}$ と硬度 $\mathrm{HV}^{\prime}$ の関係を $\mathrm{HV}^{\prime}=\left\{W^{\prime}\right\}^{C}$ で近似 した結果，次式のような関係を得た (図中の実線).

$$
\begin{aligned}
& \mathrm{HV}^{\prime}=\left\{W^{\prime}\right\}^{0.84} \text { for } 110 \text { plane } \\
& \mathrm{HV}^{\prime}=\left\{W^{\prime}\right\}^{0.65} \text { for } 200 \text { plane } \\
& \mathrm{HV}^{\prime}=\left\{W^{\prime}\right\}^{0.63} \text { for } 211 \text { plane }
\end{aligned}
$$

焼入組織と焼入前組織が混在した中間組織では，照射領 域内の硬度のばらつきが認められるが，上式の近似曲線 に良く乗っていることがわかる。よって，照射位置の硬 度 HV は，式 (4)または式 (5)，式 (6) を式 (3)に代入する ことにより

$$
\begin{gathered}
\mathrm{HV}=\left(\frac{W-W_{\text {min }}}{W_{\text {max }}-W_{\text {min }}}\right)^{0.84}\left(\mathrm{HV}_{\text {max }}-\mathrm{HV}_{\text {min }}\right)+\mathrm{HV}_{\text {min }} \\
\text { for } 110 \text { plane } \\
\mathrm{HV}=\left(\frac{W-W_{\text {min }}}{W_{\text {max }}-W_{\text {min }}}\right)^{0.65}\left(\mathrm{HV}_{\text {max }}-\mathrm{HV}_{\text {min }}\right)+\mathrm{HV}_{\text {min }} \\
\text { for } 200 \text { plane }
\end{gathered}
$$

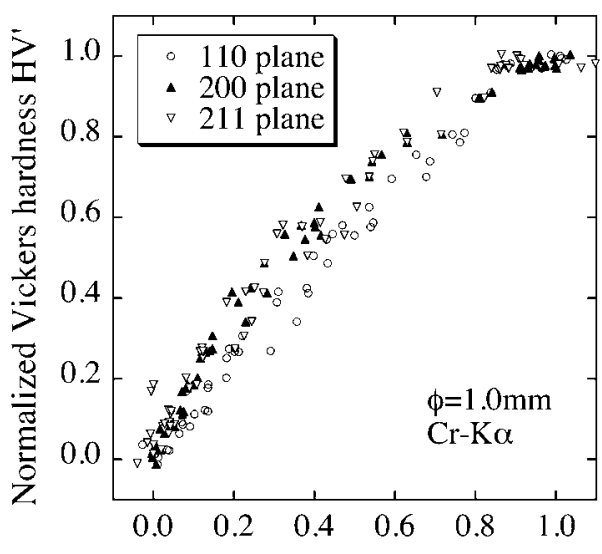

Normalized 2/5-value breadth $W^{\prime}$

Fig. 9 Relationship between normalized $W^{\prime}$ and $\mathrm{HV}^{\prime}$ measured by micro X-ray beam using $\phi 1.0 \mathrm{~mm}$ collimator.

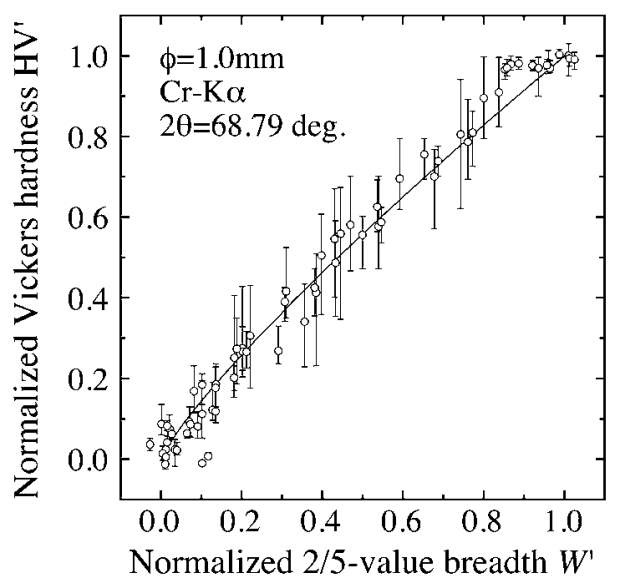

(a) 110 plane

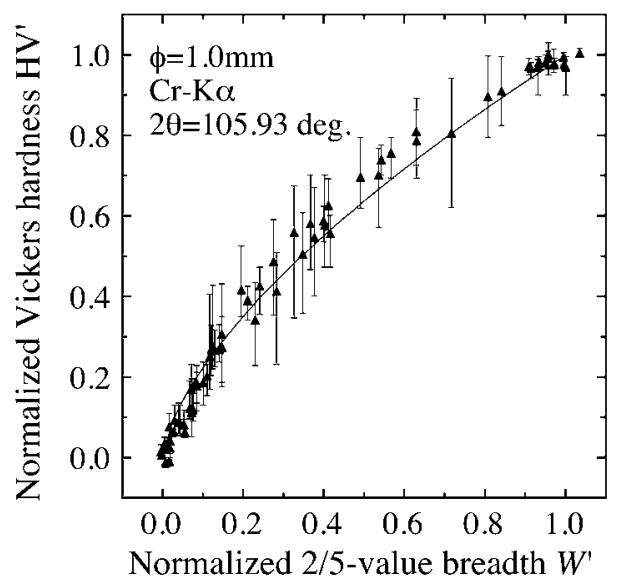

(b) 200 plane

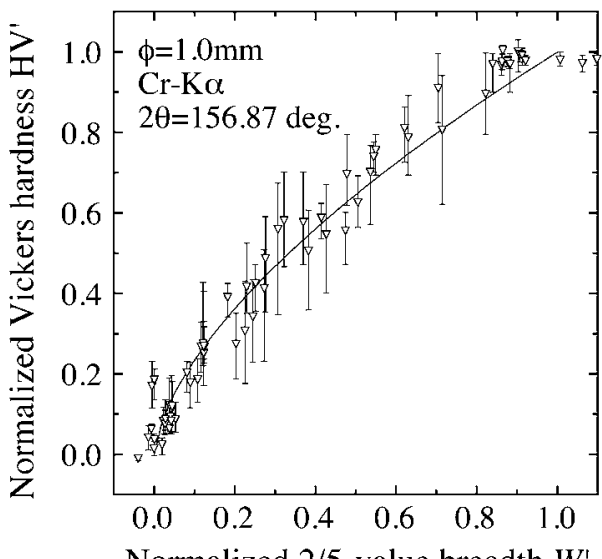

Normalized 2/5-value breadth $W^{\prime}$

(c) 211 plane

Fig. 10 Relationship between $W^{\prime}$ and $\mathrm{HV}^{\prime}$ for each diffraction plane at $\phi 1.0 \mathrm{~mm}$ collimator.

$$
\mathrm{HV}=\left(\frac{W-W_{\text {min }}}{W_{\text {max }}-W_{\text {min }}}\right)^{0.63}\left(\mathrm{HV}_{\text {max }}-\mathrm{HV}_{\text {min }}\right)+\mathrm{HV}_{\text {min }}
$$$$
\text { for } 211 \text { plane }
$$

で表され， $\phi 1.0 \mathrm{~mm}$ のコリメータでマイクロビーム化し た X 線で高周波焼入鋼の回折線幅 $W$ を測定することに より非破壊で求めることができる. 


\section{$3 \cdot 4$ コリメータ径 $\phi 0.1 \mathrm{~mm}$ による回折線幅の測定 結果}

Fig. 11 は，コリメータ径 $\phi 0.1 \mathrm{~mm}$ による $2 / 5$ 值幅 $W$ とビッカース硬度 HV の関係を示す。なお， $\phi 0.1 \mathrm{~mm}$ の 測定では，Fig. 7 (b)に示すように，照射領域と圧痕面 積はほぼ等しい，よって，横軸の硬度は，照射位置の硬 度 $\mathrm{HV}_{0}$ とした，図より，2/5 值幅 $W$ と硬度 $\mathrm{HV}$ の関係 は， $\phi 1.0 \mathrm{~mm}$ の場合と同様に，ほぼ比例関係を示すこと がわかる.

そこで，前節と同様に Table 3 に示す焼入組織のマル テンサイト相の $W_{\text {max }}$ と $\mathrm{HV}_{\text {max }}$ を 1 , 焼入前組織のフェライ 卜相の $W_{\text {min }}$ と $\mathrm{HV}_{\text {min }}$ を 0 として規格化した結果を Fig. 12 に示す。また，Fig. 13 は，2 つの回折面に対し， $W^{\prime}$ と $\mathrm{HV}^{\prime}$ の関係をそれぞれプロットした結果を示す。なお， 図中のエラーバーは照射位置周りの 4 点の硬度から求め た硬度誤差である。罒より, 回折線幅 $W^{\prime}$ と硬度 $\mathrm{HV}^{\prime}$ の 関係は，前節と同様に，110面は式 (4)で，211 面は式 (6) で表された。一方，コリメータ径を小さくして照射領域 を小さくすると, 柬底面内の硬度変化が激しい中間組織 での評価においては，照射位置の硬度を反映して回折

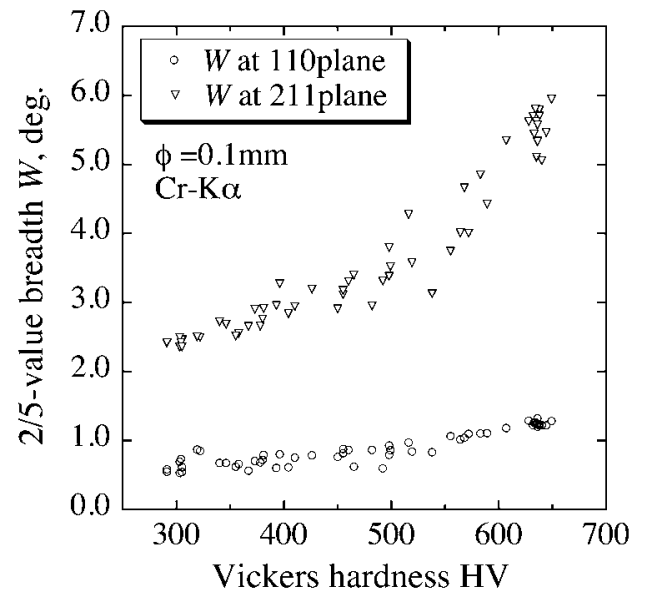

Fig. 11 Relationship between HV and $W$ measured by micro X-ray beam using $\phi 0.1 \mathrm{~mm}$ collimator.

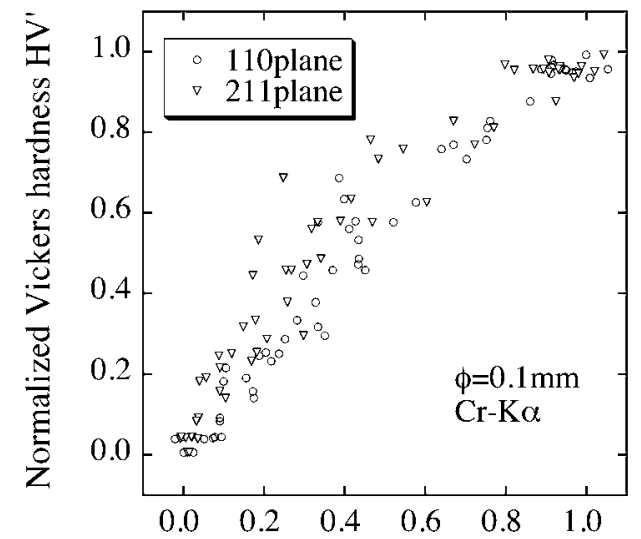

Normalized 2/5-value breadth $W^{\prime}$

Fig. 12 Relationship between normalized $W^{\prime}$ and $\mathrm{HV}^{\prime}$ measured by micro X-ray beam using $\phi 0.1 \mathrm{~mm}$ collimator.

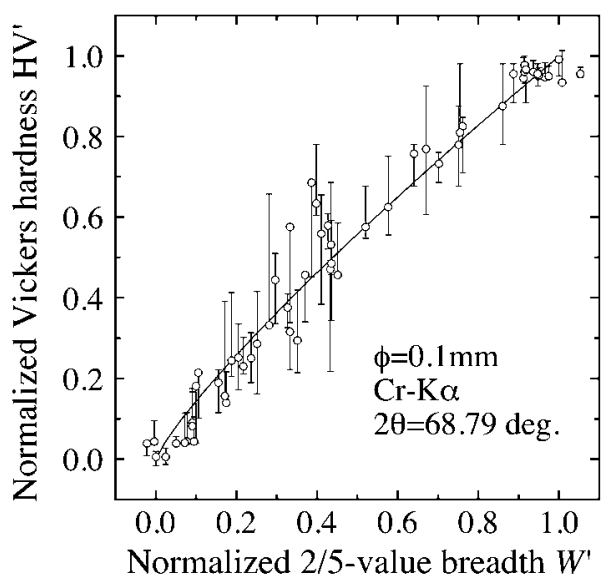

(a) 110 plane

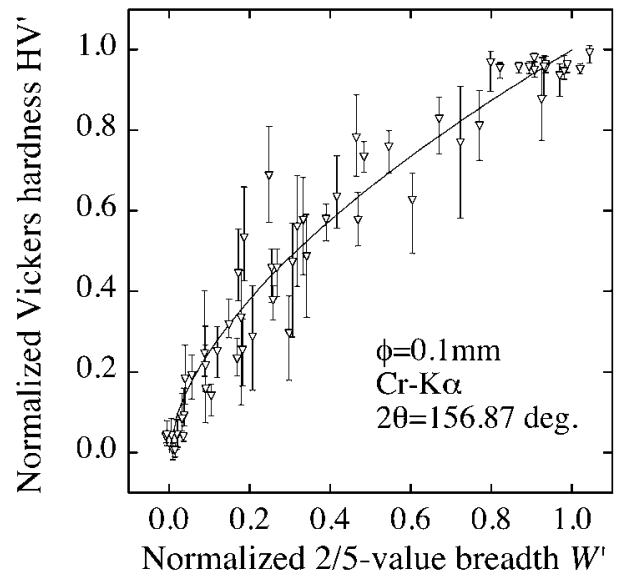

(b) 211 plane

Fig. 13 Relationship between $W^{\prime}$ and $H^{\prime} V^{\prime}$ for each diffraction plane at $\phi 0.1 \mathrm{~mm}$ collimator.

線幅 $W^{\prime}$ と硬度 $\mathrm{HV}^{\prime}$ の関係精度は良くなると予想してい たが，前節の結果と比較すると，逆にばらつきは大きく なった. $\phi 0.1 \mathrm{~mm}$ の測定では, 空間分解能が高くなる反面, Fig. 3 の組織写真からわかるように回折に預かる粒子数 が大きく減少するため, 回折線幅の測定精度は $\phi 1.0 \mathrm{~mm}$ と比較すると低い。爷のため, $\phi 0.1 \mathrm{~mm}$ では, 式 (4)または 式 (6)の実線に対するばらつきが， $\phi 1.0 \mathrm{~mm}$ の結果よりも 大きくなったと考えられる。な打，本研究のX線による 照射位置と硬度測定点の設定誤差は，それぞれ $\pm 10 \mu \mathrm{m}$ 以下と $\pm 1.0 \mu \mathrm{m}$ 程度であり，X線照射位置の設定誤差に よる硬度のばらつきはほとんど無視できると考えられる。 しかし，実際の生産ラインで， $\phi 0.1 \mathrm{~mm} の \mathrm{X}$ 線よる非破 壊評価を行うと，X線照射位置の設定誤差内に著しい硬 度変化が存在する場合は注意する必要がある.

\section{$3 \cdot 5 \quad X$ 線による硬化層深さの予測}

前節までの結果から，高周波焼入したドライブギアの 硬度は，マイクロビーム化したX $\mathrm{X}$ 線で回折線幅 $W$ を測 定することにより非破壊評価できることがわかった。一 方, 焼入状態の判断には, 表面硬さの他に, 硬化層深さ の評価が必要である。本研究では, X 線による回折線幅 と硬度の関係を利用し, 検査対象部品の最適な焼入状態 での硬度分布から，焼入部品の表面硬さと硬化層深さを 


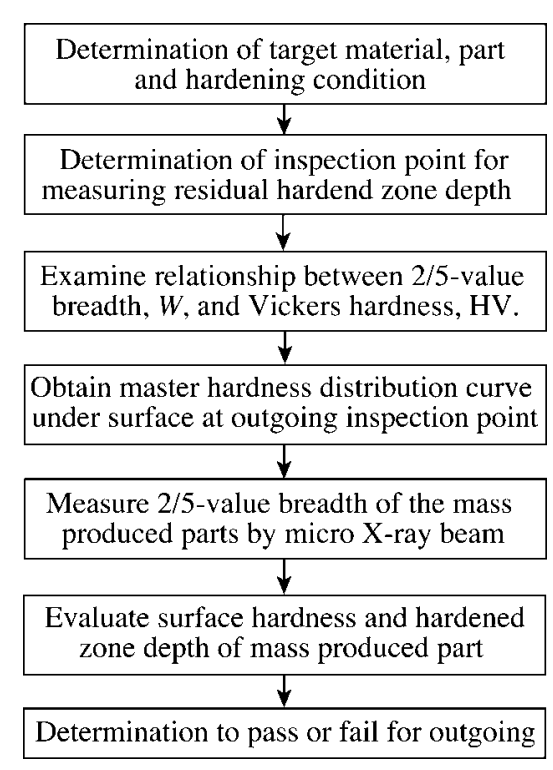

(a) Flowchart of outgoing inspection
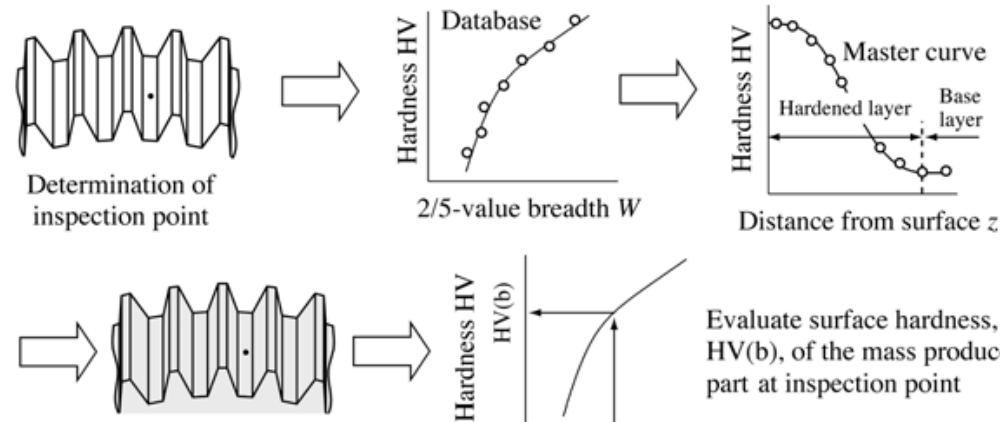

Measure 2/5-value breadth, $W($ a), of the mass produced part

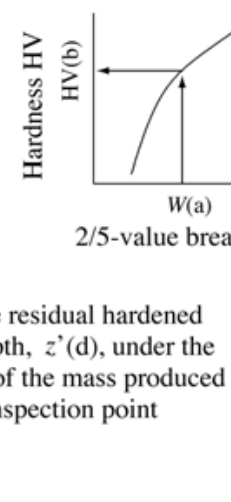

tance from surface $z$

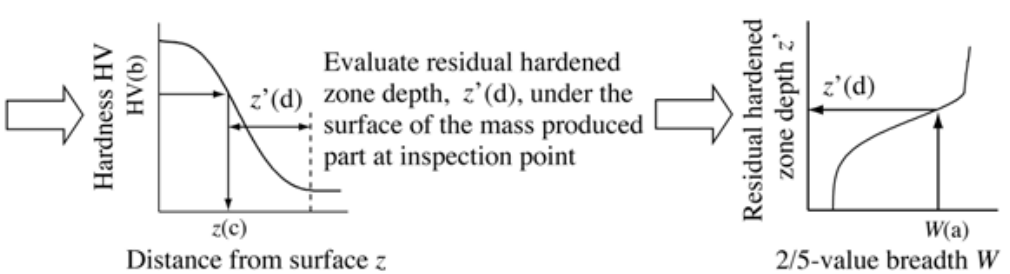

(b) Evaluation of surface hardness and residual hardened zone depth

Fig. 14 Outgoing inspection method of induction hardening for mass produced parts by micro X-ray beam.

非破壊検査する方法を検討した。非破壊検査の流れと評 価手順をそれぞれ Fig. 14 (a) と Fig. 14 (b)に示す.

まず，対象材料と部品を決定し，最適な焼入処理を施 したマスター部品の硬化層組織を観察し, 表面硬さと硬 化層深さを確認すべき検査位置を決める。たとえば，本 研究で用いたドライブギアでは，Fig. 14 (b)に示したよう な歯底中央部などが検査位置となる。次に，対象部品の 回折線幅と硬度の関係 (Fig. 8 または Fig. 9) を実験的に 求め, 式 (7) や式 (8), 式 (9)のようなデータベースを構築 する，また，マスター部品の検査位置での深さ方向の硬 度分布を測定し, 硬化層のマスターカーブとする。なお， 硬化層深さは焼入条件や検査位置により異なるので, 検 查位置に対応したマスターカーブ (後述する Fig. 17 参照) が必要となる。

次に，実際の量産部品に X 線を照射し，回折線幅 $W(\mathrm{a})$ を測定し，マスター部品のデータベースから検査位 置の表面硬さ HV (b) を評価する。ついで, 硬化層のマス ターカーブから HV (b)に対応する深さ $z(\mathrm{c})$ を求め, 検査 位置の表面下に残留する硬化層深さ $z^{\prime}(\mathrm{d})$ を評価する。 な お，X線法では同時に検査位置の回折パターンを確認で きるので，熱処理の不具合などにより生じる異相（残留 オーステナイトなど）の発生に伴う硬度低下部品を非破 壊で除去することができる。

実際の㐘車部品では，焼入処理後に㐘部表面を研磨な どの機械加工により除去して出荷するため, マスター部 品の硬化層深さに満たない量産部品が発生する危険性が 高い.そこで, Fig. 15 に示すように, 実験に用いた切出 し試験片の柬底中央部近傍の A 点を検査位置と仮定し, 㐘底面を任意に研磨除去した別の試験片に対して回折線 幅を測定して表面下の残留硬化層深さを予測し，その後 機械研磨により焼入前組織が観察されるまでの深さを実 測して本手法の妥当性を検討した。なお，検査位置によ

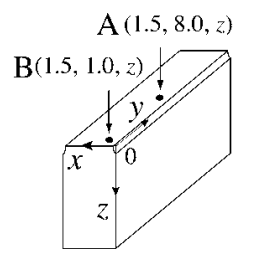

(a) Master part and inspection points

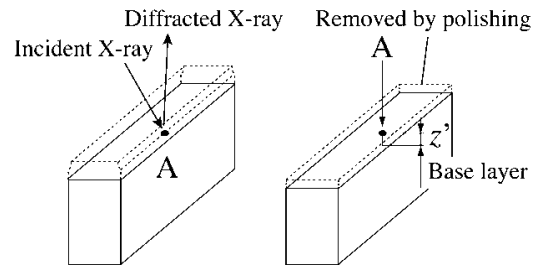

(b) Prediction and measurement of residual hardened zone depth
Fig. 15 Schema of verification for prediction of residual hardened zone depth from the measured 2/5-value breadth.

るマスターカーブの違いを見るために B 点を定義した.

Fig. 16 は, 式 (7) と式 (8), 式 (9)から予測したドライ ブギア硬化層の回折線幅と硬度の関係を示す。眓より， 一定の硬度変化に対する回折線幅の変化量は，高角度側

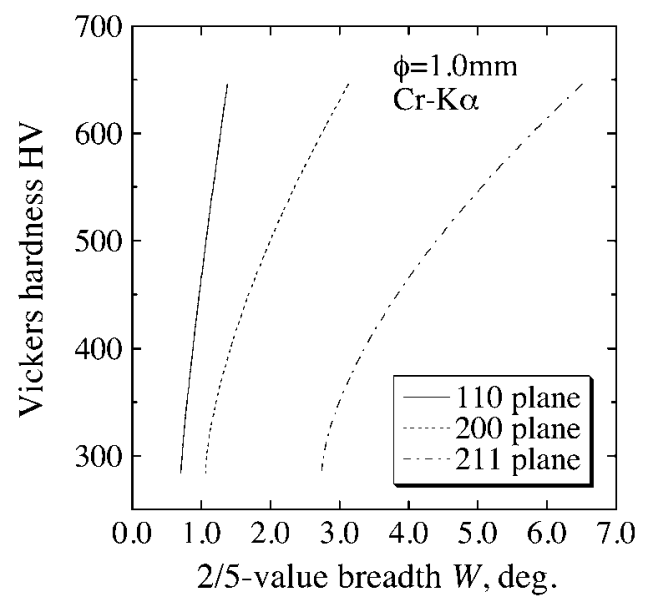

Fig. 16 Database of 2/5-value breadth and Vickers hardness of target material for inspection object (S48C drive gear wheel). 
の 211 面が最も高く，200 面，110 面と低角度になるほ ど小さくなる．回折線幅による硬度評価も X 線残留応力 測定と同様に，高角度側の回折角を選択するほど微小な 硬度変化を精度良く捉えられることを示している。

次に, Fig. 17 は, 歯底中央部近傍の A 点と柬車側面 近傍の B 点に打ける柬車軸方向の硬度分布を示す。なお， 図中の実線と点線は実験值の補間曲線で，これらの曲線 を検査位置における硬化層のマスターカーブとした。検 查位置 $\mathrm{A}$ では， $z \geqq 3.6 \mathrm{~mm}$ で高周波焼入による焼入組織 がほほ観察されなくなり，焼入前組織の硬度と一致した。

Fig. 18 は，回折線幅 $W$ に対する検查位置 $\mathrm{A}$ の試験片 表面下に残留する硬化層深さ $z^{\prime}$ を示す。図中の 3 つの曲 線が 110，200，211面の回折線幅に対する予測值で, Fig. 16 と Fig. 17 から求めた。 な打, 図の各点 $(\bigcirc$, 山，口印）は，柬底面を任意に研磨除去した別の試験片 の検査位置 A で測定した回折線幅と，その表面下に残留 する硬化層深さの実測值をプロットした結果である。困 より，データベースとマスターカーブから予測される硬 化層深さと実験值はほぼ一致し，本手法により焼入部品

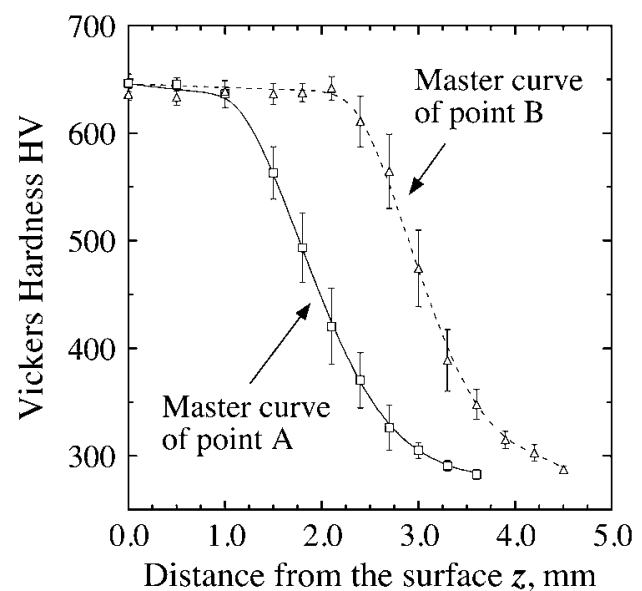

Fig. 17 Master curves for Vickers hardness at outgoing inspection points, $\mathrm{A}$ and $\mathrm{B}$, of drive gear wheel.

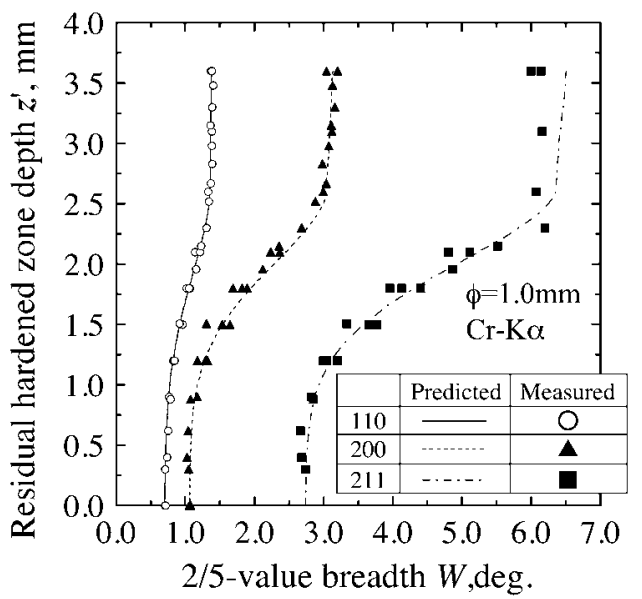

Fig. 18 Predicted residual hardened zone depth in comparison to experimental data from $\mathrm{S} 48 \mathrm{C}$ of drive gear wheel.
の表面硬さや表面下に残留する硬化層深さを非破壊で評 価でき，焼入状態の非破壊検査に適用できる可能性が高 いことが確かめられた。なお，困の 211 面の結果からも わかるように，高角側の回折面を用いた方が，表面硬さ や硬化層深さの予測精度が高い。

なお，本研究は，焼入によるマルテンサイト組織の発 生に伴う硬化層の焼入状態を非破壊検査する手法を提案 したもので，マルテンサイト組織以外の異相が発生した 場合や浸炭などの全く異なる表面硬化処理を施した場合， 焼入面の酸化層や窒化層を除去しない場合等には，硬化 層の組織や回折線幅と硬度の関係が大きく異なる可能性 があるので本手法の適用には十分注意する必要がある.

\section{4 結訔}

本研究では, 微小部 X 線を用いて高周波焼入鋼の表面 硬さと硬化層深さを非破壊評価する手法を検討した結果， 次のことが明らかとなった。

(1) 焼入組織のマルテンサイト相と焼入前組織に含ま れるフェライト相の回折線幅の変化は, 硬化層の硬度変 化とほぼ比例し，ピンホールコリメータを用いた微小部 $\mathrm{X}$ 線による回折線幅測定によって，高周波焼入鋼の表面 硬さを非破壊測定できることがわかった.

（2）微小部 X 線による硬度評価では，コリメータ径 を大きくすると X 線照射領域内の硬度変化の影響を受け るが，コリメータ径を小さくしすぎると，測定時間が長 くなったり，回折に預かる結晶粒子数が減少し，かえつ て評価精度が低下するので注意が必要である。

（3）予め最適な焼入処理を施した部品の硬化層の硬度 分布を把握することで，高周波焼入鋼表面の回折線幅か ら表面硬さと硬化層深さを非破壊評価できることがわ かった.

本研究の遂行にあたり, 試験片の加工には静岡大学の 磯谷章氏の多大な協力を得た。ここに謝意を表する。

\section{参 考 文 献}

1) R. Isomura, "Hagane-no-netsu-syori-to-zanryu-oryoku", pp.91100 (1996) Agune Gijutsu Center.

2 ) H. Koga, K. Kawasaki and T. Yamazaki, Netsu Shori, Vol.39, No.3, pp.142-151 (1999).

3 ) K. Kawasaki, Y. Misaka, Y. Kiyosawa and T. Yamazaki, Netus Shori, Vol.39, No.5, pp.257-263 (1999).

4 ) Y. Sakaida, S. Kashiwagi, K. Katagiri and Y. Sawaki, "Nondestructive Evaluation of Hardening Layers in Induction Hardened Drive Gear by X-rays”, Proceedings of the 54th JSME Tokai-branch Annual Meeting, pp.91-92 (2005).

5 ) Edited by JSMS Committee on X-ray Study on Mechanical Behavior of Materials, "Standard method for X-ray stress measurement on Carbon Steel”, pp.34-40 (1997) The Society of Materials Science, Japan.

6 ) Edited by JSMS Committee on X-ray Study on Mechanical Behavior of Materials, "Standard method for X-ray stress measurement on Ceramics”, pp.20-45 (2000) The Society of Materials Science, Japan. 